\title{
THE EFFECT OF CONCENTRATIONS OF EPHINEPHELUS SP. SKIN GELATIN ON THE QUALITY OF HALAL MARSHMALLOWS
}

\author{
Suprayitno Eddy* \\ Department of Fisheries Technology, Faculty of Fisheries and Marine Science, \\ University of Brawijaya, Indonesia \\ Fukata Editya \\ Department of Medicine, Faculty of Medicine, University of Brawijaya, Indonesia \\ *E-mail: eddysuprayitno@ub.ac.id
}

\begin{abstract}
Gelatin is a polymer of amino acids that is found in collagen in the tissues of the skin and bones of animals. The use of gelatin from pigs and cows faces the problems of halal or religious issues, and mad cow disease respectively. The aim of this research is to find out the best concentration of Epihinephelus sp. skin gelatin on the physical and organoleptic qualities of marshmallows. This research involves the process of extracting gelatin using citric acid from Epihinephelus sp. skin as the source, and the gelatin was utilized in the creation of marshmallows at $6 \%, 8 \%$, and $10 \%$ concentrations. The results of the research indicated that marshmallows from Epihinephelus sp. skin gelatin possess physical characteristics of $53.62 \mathrm{~N}$ chewiness, $72.93 \%$ elasticity, and $0.93 \mathrm{~g} / \mathrm{ml}$ density, as well as organoleptic hedonic characteristics of 3.47 texture, 3.43 taste, 3.27 aroma, and 3.50 color.
\end{abstract}

\section{KEY WORDS}

Gelatin, food technology, marshmallows, physical characteristics.

Gelatin is a water-soluble protein that is obtained from the collagen of animals through a controlled process of hydrolysis. . Gelatin is derived from collagen, which consists of three chain types ( $\alpha$-chains, $\beta$-chains, and $\gamma$-chains) that from a triple helix with counter clockwise or left-handed orientation, and this is stabilized by inter chain hydrogen bonds. Treating collagen with dilute acid or alkaline destructs the hydrogen bonds, and hence releases the triple helix conformations to coiled chain forms (Samboon et al. 2014). Gelatin acts as a gelling agent (gelling substance) or as a non-gelling agent; gelatin has a wide range of applications in various industries, both food industries and non-food industries. Gelatin in the food industry is utilized as a binder agent, stabilizer, gelling agent, adhesive, viscosity agent, and emulsifier (Minah et al., 2016). In addition, gelatin is also a foaming agent. This foaming properties are important properties of gelatin for commonly used food such as marshmallows (Zakaria et al., 2017).

According to Sasmitaloka et al. (2017), one of the important aspects that need to be considered regarding gelatin is its halal quality for Muslims. $98.5 \%$ of gelatin in the world is produced from the meat, bones, and skin of pigs; as such, there is a need to develop gelatin production from other animal sources, one of them being fish.

Epihinephelus sp.is a fish that is often utilized for its fillets and leaves fish skin waste after processing. Up to now, the utilization of fish skin waste has not been quite optimal because it is generally only processed into fish powder for low-quality animal feed, and thus there needs to be an effort to increase the utilization of fish skin waste by processing it into gelatin (Azara, 2017). In its development, gelatin became very much used and applied to a variety of innovations of foods to be consumed. Marshmallows are aerated confectionery products, wherein the production process involves the entrapment of air and a low temperature, which as a result does not decrease its nutritional content. In principle, the creation of marshmallows involves the creation of air bubbles and entrapping them in order to form a stable foam. The aerated process aims to increase the volume of air on the 
marshmallow so that it has a foamy texture. Marshmallows with low water content can extend shelf life (Fanek et al., 2012).

The aim of this research is to find out the best concentration of Epihinephelus sp. skin gelatin on the physical and organoleptic qualities of marshmallows.

\section{MATERIALS AND METHODS OF RESEARCH}

The raw materials used for the extraction of gelatin are the skin of Epihinephelus sp. (Ephinephelus sp.), obtained from the fish processing industries in Surabaya and Tuban, as well $1 \%$ citric acid and distilled water. The materials involved in the creation of marshmallows include Epihinephelus sp. skin gelatin, granulated sugar, fructose syrup, strawberry flavoring, and water. The tool used for analysis is the texture analyzer TA_XT2 (probe SMSP/35; probe distance $20 \mathrm{~mm}$; probe speed $1 \mathrm{~mm} / \mathrm{s}$; auto trigger $5 \mathrm{~g}$; and distance 50 percent)

The tools utilized in the creation of marshmallows include a stove, beaters, a mixer, pots, spoons, bowls, trays, a scale, and molds.

The extraction of gelatin from the skin of Epihinephelus sp. utilizes an acid process with $1 \%$ citric acid $\left(\mathrm{C}_{6} \mathrm{H}_{8} \mathrm{O}_{7}\right)$ with a soaking time of 24 hours. The skins were cleaned of residual meat, fat layer, and scales, and then cut into smaller pieces of $1 \mathrm{~cm}^{2}$ size and rinsed with running water. The skin was cut into small pieces to enlarge the surface area so that the solvent can more quickly penetrate the fish skin tissues. The fish skin was then soaked in $1 \%$ citric acid $\left(\mathrm{C}_{6} \mathrm{H}_{8} \mathrm{O}_{7}\right)$ for 24 hours at a ratio of $1: 3(\mathrm{~b} / \mathrm{v})$. Rinsing of the skin was performed with distilled water until the $\mathrm{pH}$ was neutral, and this was followed by the extraction stage using distilled water with a ratio of $1: 3(\mathrm{~b} / \mathrm{v})$ at a temperature of $60{ }^{\circ} \mathrm{C}-70{ }^{\circ} \mathrm{C}$ for 6 hours using a water bath. Next, draining was performed using a muslin cloth, followed by filtration with a Whatman number 42 filter. Drying was then performed in an oven at a temperature of $60{ }^{\circ} \mathrm{C}$ for 48 hours.

The marshmallows were made with the addition of gelatin from Epihinephelus sp. skin. Gelatin is added to marshmallows because it functions to form a gel. This research utilized the method of marshmallow creation from the research by Jariyah et al. (2019) modified to include gelatin concentrations of $6 \%, 8 \%$, and $10 \%$. Next, the marshmallows were tested for their physical (chewiness, elasticity, and density) and organoleptic (color, aroma, taste, and texture) characteristics. The process of marshmallow creation involves several steps. Gelatin was weighed to concentrations of $6 \%(28.6 \mathrm{~g}), 8 \%(38 \mathrm{~g})$, and $10 \%(47.6 \mathrm{~g})$ and dissolved in $250 \mathrm{ml}$ air heated to a temperature of $60{ }^{\circ} \mathrm{C}$ for 7 minutes, and then the gelatin mixture was beaten with a mixer for \pm 15 minutes until it increased in volume. 75 grams of granulated sugar and $150 \mathrm{ml}$ of fructose syrup was heated to $80^{\circ} \mathrm{C}$; the gelatin and sugar mixtures were beaten together with a mixer until combined and expanded, for \pm 15 minutes. During the mixing process, $1 \mathrm{ml}$ of strawberry flavoring was also added. The mixture was poured into a container sprinkled with cornstarch and left to stand for 24 hours at room temperature (Aziza et al., 2019).

Elasticity and chewiness were measured with the LFRA Texture Analyzer equipment (probe SMSP/35; probe distance $20 \mathrm{~mm}$; probe speed $1 \mathrm{~mm} / \mathrm{s}$; auto trigger $5 \mathrm{~g}$; and distance 50 percent). The value of elasticity was obtained as the distance between the $y$-axis and the abscissa when sample deformation occurred, measured in $\mathrm{mm}$.

Density was measured using an equipment composed of a glass cylinder of a height of approximately $400 \mathrm{~mm}$, diameter of $75 \mathrm{~mm}$, and a burette volume of $25 \mathrm{ml}$; it is welded to the top and fitted with a plastic lid and plunger with a screw for fixation at the perfect height in the middle of the lid. Density is determined by the volume of toluene that is displaced when the marshmallow sample is dropped; the fractional mass of the reducing substance is determined by the ferricyanide method.

\section{RESULTS AND DISCUSSION}

Chewiness is one of the important factors in determining the quality of marshmallows. Chewiness may be affected by the water content of the resulting marshmallows. The testing 
of chewiness of marshmallows utilized texture analyzer equipment (Devi et al., 2018). The results of average chewiness of marshmallows made with Epihinephelus sp. skin gelatin are presented in Figure 1.

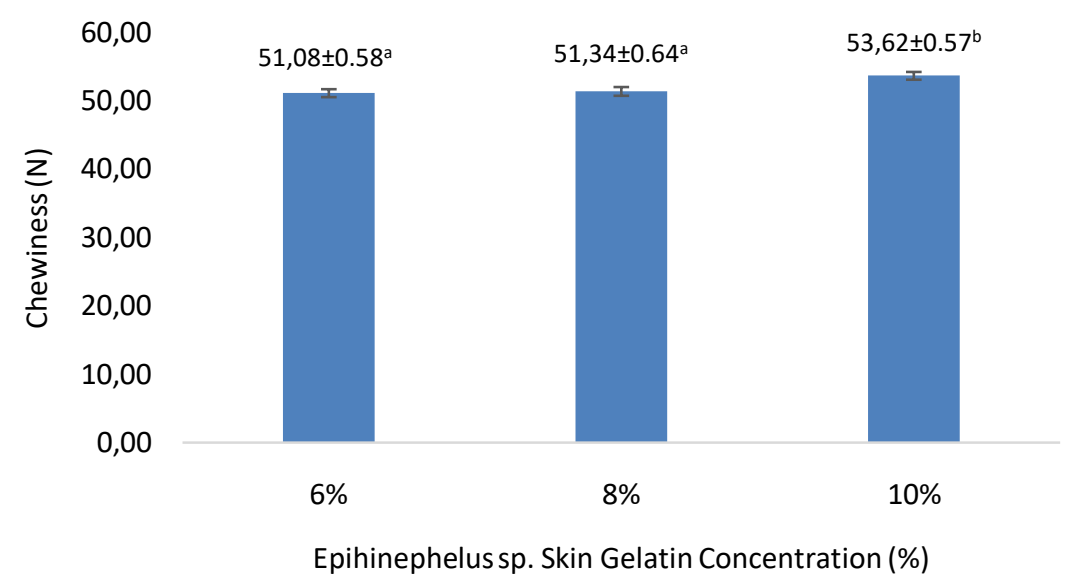

Figure 1 - Chewiness of Marshmallow

For the research results, it was found that the highest chewiness for marshmallows are those made with a concentration of $10 \%$ gelatin. At gelatin concentrations of $8 \%$ and $6 \%$, the chewiness decreased due to differences in the utilized concentrations of gelatin. A higher gelatin concentration leads to greater chewiness of marshmallows. This is affirmed by Sebayang et al. (2017), who found that the addition of stabilizers such as gelatin in higher concentrations resulted in marshmallows that are more chewy and soft. According to Calvarro et al. (2012), gelatin is commonly used as a gelling and foaming agent in many culinary preparations. Gels made with gelatin are very appreciated by chefs and consumers, due to their unique texture features: very soft and easily melting in the mouth before swallowing.

Elasticity is the rheological nature of plastic food products toward resistance to breakage due to forces of pressure and stretching that may cause changes in shape (deformation). Pressure and stretching of a product initially causes changes that may finally break the final product. The elasticity value is in an inverse relationship with the hardness value. A higher elasticity value leads to a lower hardness value on Figure 2.

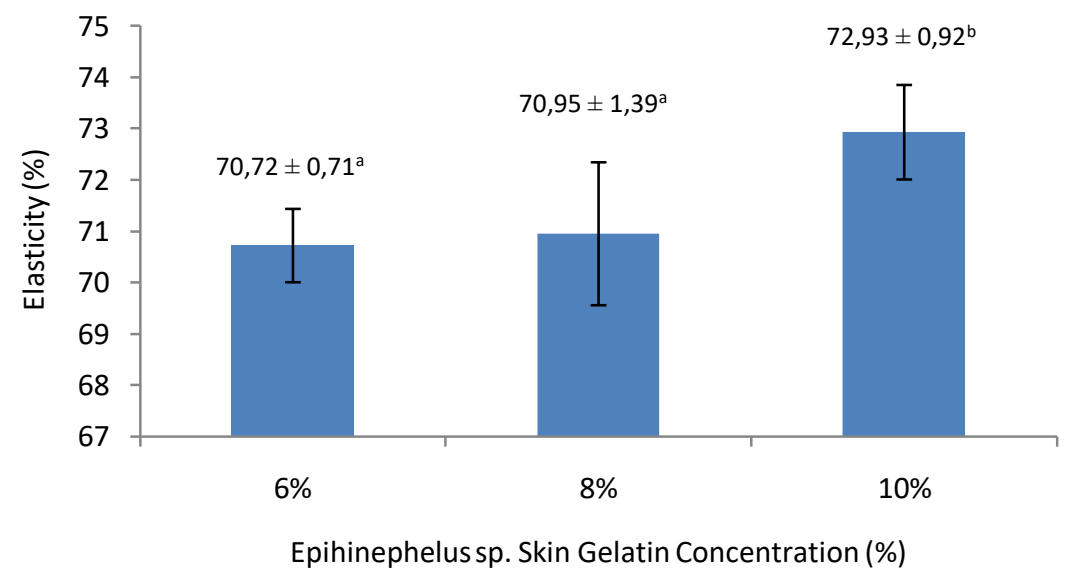

Figure 2 - Elasticity of Marshmallow

For the research results, it was found that the highest elasticity $(72.93 \%)$ was for marshmallows made with a gelatin concentration treatment of $10 \%$ and the lowest $(70.72 \%)$ 
was for those made with a gelatin concentration treatment of $6 \%$. The elasticity of marshmallows is affected by the gelling agent that makes them chewy. Gelatin has the ability of binding with proteins, which enables marshmallows to be able to withstand external pressure and return to its original shape after the pressure is removed. The low concentration of gelatin in marshmallows causes the gel strength to be low, and thus the elasticity value of marshmallows becomes low at the given pressure (Aziza et al., 2019).

Density is an important parameter that is used to determine the quality of marshmallows. The density value has a direct relationship with the weight of marshmallows and has an inverse relationship with the volume of marshmallows. A low density value indicates marshmallows that are of good quality. This is because marshmallows with low density values have more air trapped within them, making them softer and lighter.

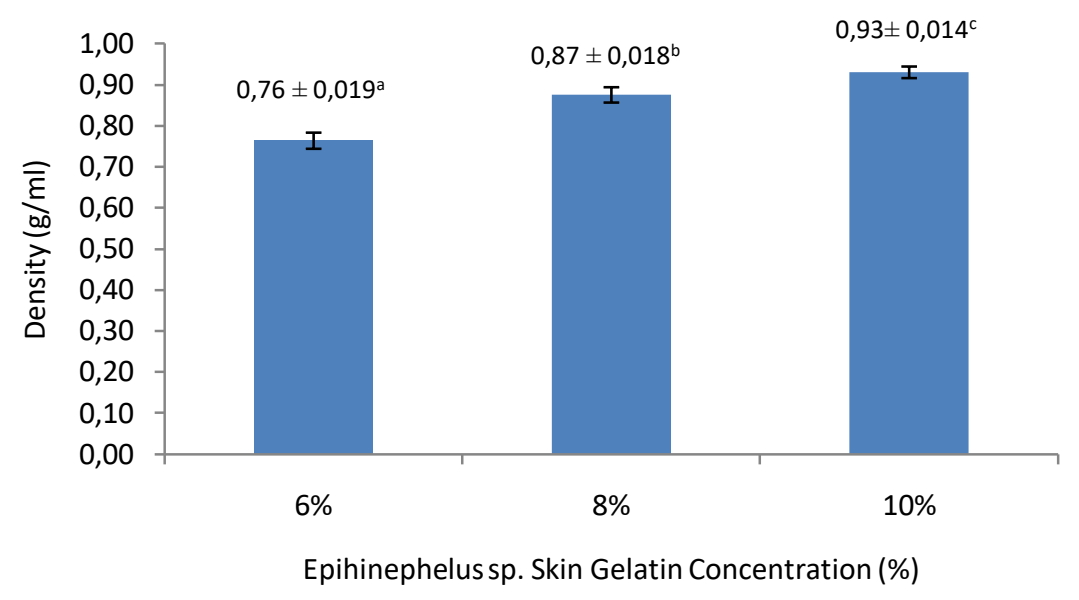

Figure 3 - Density of Marshmallow

The average density of marshmallows made with Epihinephelus sp. skin gelatin at a concentration treatment of $6 \%$ was $0.76 \mathrm{~g} / \mathrm{ml}$, at a concentration treatment of $8 \%$ was 0.87 $\mathrm{g} / \mathrm{ml}$, and at a concentration treatment of $10 \%$ was $0.93 \mathrm{~g} / \mathrm{ml}$. The highest average density was for the concentration treatment of $10 \%$, being $0.93 \mathrm{~g} / \mathrm{ml}$, and the lowest was for the concentration treatment of $6 \%$, being $0.76 \mathrm{~g} / \mathrm{ml}$. Density in the study of Artamonova et al. (2017), amounting to $0.51-0.67 \mathrm{~g} / \mathrm{ml}$. Density can affect the elasticity rating of marshmallows.

A low density value indicates a better quality of marshmallows, in comparison to a high density value. Higher concentrations of gelatin will result in a lower density value. This is because a higher concentration of gelatin will lead to a higher volume of air being trapped during beating, and thus the resulting product will become lighter (Zulfajri et al., 2018). The density of marshmallows decreases as marshmallows develop. Marshmallows may be either non-grained or grained crystal aggregate, depending on the ratio of sucrose to corn syrup (Nasreen et al., 2017).

Organoleptic analysis has the aim to find out the level of acceptance that a group of panelists have toward marshmallows made with Epihinephelus sp. skin gelatin. Organoleptic analysis is one of the methods to evaluate a food product by using human senses, as sight with eyes, smell with the nose, taste with the tongue, and touch with the skin. In this research, organoleptic testing was conducted with a hedonic or preferential method by evaluating with scores of $1=$ strong dislike, $2=$ dislike, $3=$ like, and $4=$ strong like. The utilized number of panelists was 30 people; the minimum number of untrained panelists is 30 people (BSN, 1992). The evaluated parameters are color, aroma, flavor, and texture. Data from the organoleptic testing was then analyzed using the Kruskal-Wallis test. The results of organoleptic testing are presented in Table 1.

The highest value for the hedonic parameter of color is for marshmallows given the treatment of $10 \%$ gelatin (3.50), while the lowest value is for the treatment of $6 \%$ gelatin (3.17). The hedonic parameter of color ranging from 3.17-3.50 for all gelatin treatments 
indicates that the panelists liked the color of the marshmallows. This is because the utilized Epihinephelus sp. skin gelatin is colorless and thus does not affect the color of the marshmallows. The color of the marshmallows is dominated by the food coloring added to the marshmallow mixture.

Table 1 - Result of Organoleptic Testing

\begin{tabular}{ccccc}
\hline Gelatin Concentration & Color & Aroma & Flavor & Texture \\
\hline $6 \%$ & $3.17 \pm 0.65$ & $2.86 \pm 0.64$ & $3.13 \pm 0.51$ & $2.97 \pm 0.76$ \\
$8 \%$ & $3.37 \pm 0.67$ & $3.13 \pm 0.68$ & $3.17 \pm 0.70$ & $3.13 \pm 0.78$ \\
$10 \%$ & $3.50 \pm 0.63$ & $3.27 \pm 0.64$ & $3.43 \pm 0.63$ & $3.47 \pm 0.63$ \\
\hline
\end{tabular}

The highest value for the hedonic parameter of aroma is for marshmallows given the treatment of $10 \%$ gelatin (3.27), while the lowest value is for the treatment of $6 \%$ gelatin (2.86). The hedonic parameter of aroma ranging from 2.86-3.27 for all gelatin treatments indicates that the panelists liked the aroma of the marshmallows. The aroma of the marshmallows originate from the aromas of the essence, the granulated sugar and fructose syrup, as well as the Epihinephelus sp. skin gelatin. The aromas of the essence and sugar in the marshmallows are able to cover up the aroma of the fish gelatin. Fish gelatin in general has a fishy aroma that panelists find unpleasant (Aziza et al., 2019). If a product has an unfavorable aroma, the product is less favored by panelists. Aroma arises because of the combination of the ingredients that make up the product (Caesar et al., 2019)

The highest value for the hedonic parameter of flavor is for marshmallows given the treatment of $10 \%$ gelatin (3.43), while the lowest value is for the treatment of $6 \%$ gelatin (3.13). The hedonic parameter of flavor ranging from 3.13-3.43 for all gelatin treatments indicates that the panelists liked the flavor of the marshmallows. The flavor of the marshmallows are composed of the sucrose and fructose syrup, which have a sweet taste. In addition, the flavor is affected by the strawberry essence added to the mixture. The addition of gelatin does not influence the parameter.

The highest value for the hedonic parameter of texture is for marshmallows given the treatment of $10 \%$ gelatin (3.47), while the lowest value is for the treatment of $6 \%$ gelatin (2.97). The hedonic parameter of texture ranging from 2.97-3.47 pa for all gelatin treatments indicates that the panelists liked the texture of the marshmallows. The increasing gelatin concentrations added to the marshmallow mixtures have a direct relationship with the increased hedonic score of the panelists. It is known that the stability of gelatin foams increases with the amount of gelatin. This effect could be partially due to the more stable structure of the protein network in the bubble walls due to the achieved protein crosslinking (Calvarro et al., 2016).

\section{CONCLUSION}

The results of the research indicated that the addition of Epihinephelus sp. skin gelatin is optimal for the concentration of $10 \%$, which has significant effects on physical $(53.62 \mathrm{~N}$ chewiness, $72.93 \%$ elasticity, $0.93 \mathrm{~g} / \mathrm{ml}$ density) and organoleptic hedonic (3.47 texture, 3.43 flavor, 3.27 aroma, and 3.50 color) characteristics.

\section{REFERENCES}

1. Ann, K. C., T. I. P. Suseno and A. R. Utomo. 2012. Pengaruh perbedaan konsentrasi ekstrak bit merah dan gelatin terhadap sifat fisikokimia dan organoleptik marshmallow beet [The influence of concentrations of red beets and gelatin on the physical chemical and organoleptic characteristics of beet marshmallows]. Journal of Food and Nutrition. Vol 11 (2): 28-38.

2. Artomonova, M., I. Plilugina., O. Samokhvalova., N. Muriykina., O. Kravchenko., I. Fomina and A. Grigorenko. 2017. A study of properties of marshmallow with natural 
anthocyanin dyes during storage. Eastern-European Journal of Enterprise Technologies. 11 (87): 23-30. ISSN 1729-3774

3. Azara, R. 2017. Pembuatan dan analisis sifat fisikokimia gelatin dari limbah kulit ikan kerapu [Creation and analysis of the physical chemical characteristics of gelatin from Epihinephelus sp. skin waste]. Jurnal REKAPANGAN. Vol. 11 (1): 62-69

4. Aziza, I. N., Y. S. Darmanto and R. A. Kurniasih. 2019. Pengaruh gelatin dari kulit ikan yang berbeda terhadap karakteristik fisik dan sensori produk marshmallow [The influence of gelatin from different types of fish skin on the physical and sensory characteristics of marshmallow products]. Jurnal Perikanan. Vol 21 (1): 17-23. ISSN: 2502-5066.

5. Badan Stadardisasi Nasional. 1992. Standar Nasional Indonesia: SNI 01-2891-1992 (Cara Uji Makanan dan Minuman [Methods of Food and Drink Testing]). SNI 01-2891-19. Jakarta: Badan Stadardisasi Nasional.

6. Caecar, L. M., Junianto, K. Haetani and I. Rostini. The effect of Osteochilus hasselti (Valenciennes, 1842) bone gelatin addition toward jelly candy's preferences level. World Scientific News. 127 (3): 139-152. ISSN 2392-2192.

7. Calvarro, J., Perez-Palacios, T., \& Ruiz, J. 2016. Modification of gelatin functionality for culinary applications by using transglutaminase. International Journal of Gastronomy and Food Science. Vol. 5: 27-32.

8. Calvarro, J., T. P. Palacios and J. Ruiz. Modification of gelatin functionality for culinary applications by using transglutaminase. International Journal of Gastronomy and Food Science. 5 (2016): 27-32.

9. Devi, N. P. A., P. A. S. Wipradnyadewi, and N. M. Yusa. 2018. Pengaruh penambahan terung belanda (Solanum betaceum Cav.) terhadap karakteristik marshmallow [The influence of the addition of tamarillos (Solanum betaceum Cav.) on the characteristics of marshmallows]. Jurnal IImu Teknologi Pangan. 7 (1): 23-32.

10. Fanek, H., C. Fava and E. C. Huang. 2012. Determination of effective diffusion coefficient of water in marshmallow from drying data using finite difference method. International Food Research Journal. 19 (4):1351-1354.

11. Jariyah., Rosida and D. C. Nisa. 2019. Karakteristik marshmallow dari perlakuan proporsi ciplukan (Physalis peruviana L) dan jeruk manis (Citrus sinensis) serta penambahan gelatin [Characteristics of marshmallows with treatments of gooseberry (Physalis peruviana $L$ ) and sweet orange (Citrus sinensis) proportions and the addition of gelatin]. Jurnal Teknologi Pangan. Vol 13 (1): 28-38. ISSN: 2664-5292.

12. Minah, F. N. 2016. Ekstraksi gelatin dari hidrolisa kolagen limbah tulang ikan tuna dengan variasi jenis asam dan waktu ekstraksi [Extraction of gelatin from the hydrolysis of collagen from tuna fish bone waste with variations of acid types and extraction time]. Jurnal Teknologi Industri. Vol.1(1):1-7. ISSN: 2058-4218.

13. Nasreen, M. 2017. Evaluation of sensory, physicochemical changes of marshmallow (childer candy) by addition natural colors. Bulletin of the National Nutrition Institute of the Arab Republic of Egypt. 50 (1): 219-243.

14. Sasmitaloka, K.S. 2017. Kajian potensi kulit sapi kering sebagai bahan dasar produksi gelatin halal [A study on the potential of cow skin as the raw material for halal gelatin production]. Bulletin Peternakan. Vol. 41 (3): 328-337. ISSN: 0126-4400

15. Sebayang, E. F. B. 2017. Pengaruh perbandingan bubur kweni dengan sari jeruk manis dan jumlah gelatin terhadap mutu marshmallow [Comparison of the influence of kweni mango pulp with orange juice and gelatin amounts on the quality of marshmallows]. Jurnal Rekayasa Pangan dan Pertanian. Vol. 5 (1): 81-88.

16. Somboon, N. 2014. Properties of gels from mixed agar and fish gelatin. International Food Research Journal. Vol. $21(2):$ 485-492.

17. Zakaria, S., H. S. Zainal and W. A. Rahman. 2017. The properties of gelatin from the skin of terubuk fish (tenualosa toli). Journal of Solid State Science and Technology. Vol. 25 (2): 79-85 ISSN 0128-7389.

18. Zulfajri., N. 2018. Perbedaan konsentrasi gelatin terhadap kualitas permen marshmallow buah naga merah [Differences in gelatin concentrations on the quality of red dragon fruit marshmallow confection quality]. SAGU. Vol 17 (1): 10-18. ISSN: 1412-4424. 